\title{
Možnosti státu při řešení problémů veřejných rozpočtů po pandemii
}

\section{State possibilities of solving problems of public budgets after a COVID 19 pandemic}

\author{
prof. JUDr. Hana Marková, CSc. ${ }^{1}$
}

DOI https://doi.org/10.33542/SCD21-0043-1-17

\begin{abstract}
Abstrakt
Historie zná různé varianty řešení situací při nedostatku př́ijmů na úhradu společenských potřeb. Zvolené řešení odráželo možnosti, které stát měl v dané etapě vývoje. Byly to zejména daně, a proto $\mathrm{k}$ významným úpravám daní docházelo zejména $\mathrm{v}$ souvislosti s výraznými společenskými změnami. V současné době vznikla nutnost řešit dopady pandemie Covidu 19, hledají se cesty, jak pokrýt nutné rozpočtové výdaje, se kterými stát nepočítal. Nabízí se možnost další daňové reformy se zavedením nových daní či podstatnými změnami u stávajících daňových plateb nebo cesta zvyšování státního dluhu. Reálnější cestou se jeví změny v daňové soustavě (zavedení sektorových daní v různé podobě či změna DPH). Rozpočty územních samospráv jsou primárně národní záležitostí a v ČR by mohly být posíleny zavedením místních daní - např. přeměnou a doplněním stávajících místních poplatků.
\end{abstract}

\section{Klíčová slova:}

veřejný rozpočet, daňová reforma, sektorová daň, místní daň

\begin{abstract}
History cognises various options for dealing with situations of lack of income to reimbursement of costs of the social needs. The chosen solution reflected the possibilities that the state had at a given stage of development. These were mainly taxes, and therefore significant tax adjustments were made mainly in connection with remarkable social changes. At this moment, it is necessary to deal with the impacts of the Covid 19 pandemic, therefore ways are being sought to cover the necessary budgetary expenditures that the state did not anticipate. There is a possibility of further tax reform with the introduction of new taxes or substantial changes in existing tax payments or a way of increasing government debt. Changes in the tax system (such as introduction of sectoral taxes in various forms or change in VAT) seem to be a more realistic way. Local government budgets are primarily a national matter and could be strengthened in the Czech Republic by introducing local taxes - for example, by changing and supplementing existing local fees.
\end{abstract}

\footnotetext{
${ }^{1}$ Professor for Financial Law, Department of Financial Law, Faculty of Law, Charles University, Czech Republic. This paper has been elaborated within the programme "PROGRES Q02 - Publicization of Law in the European and International Context" which is realized in 2019 at the Faculty of Law of the Charles University. Contact email: markova@prf.cuni.cz. ORCID: 0000-0002-0204-4571.
} 


\section{Key words:}

public budget, tax reform, sector tax, local tax

JEL kód: K39

\section{1. ÚVODEM K HISTORII DAŇOVÝCH REFOREM NA ÚZEMÍ ČR}

Daně jsou už od vzniku státu hlavním zdrojem jeho př́immů a záleží na potřebách vládců či vlád $v$ dané době, jak vysoké tyto př́ijmy budou. Za nejstarší formu platby lze považovat naturální daň v podobě obětí bohům, kteří byli považováni za strážce státnosti. Později si panovník zpravidla bral podíl na kořisti tj. naturální plnění. Ve středověku se už můžeme setkat $\mathrm{s}$ některými specifickými daněmi jako byla daň $\mathrm{z}$ cihel či plnovousů, ale i řadou dalších. ${ }^{2} \mathrm{~V}$ této době se začínají objevovat ekonomické teorie odůvodňující jednotlivé povinné platby zejména daně. Za začátek vědeckého zpracování nauky o daních se zpravidla považuje spis Adama Smitha z roku 1776 "Wealth of Nations", kde autor argumentoval, že zdaňování nemůže být překážkou pracovitosti a pilnosti a považoval za neprŕípustné, aby stát zjištoval osobní př́ijmy občanů. Současně formuloval pro daně tyto čtyři známé zásady:

1. Poddaní každého státu mají přispívat na fungování vlády v závislosti od svých možností.

2. Daň musí byt' určitá a ne libovolná.

3. Každou daň je třeba vybírat $\mathrm{v}$ čase a způsobem, které jsou pro plátce daně nejvýhodnější.

4. Každá daň má být koncipována tak, aby daňové zatížení jednotlivce se v zásadě rovnalo míře jeho př́íspěvku pro státní rozpočet. ${ }^{3}$

Napoleonův výrok z roku 1804 „,̌ídit velký stát předpokládá mít dostatek soudců, početnou policii, mnoho vojska... a mnoho peněz"44 odstartoval rozšíření daňové povinnosti. Byly zavedeny nepřímé daně na tabák, karty, všechny předměty z drahých kovů, na alkohol, ale hlavním prostředkem k zlepšení stavu státních financí se stalo důsledné vybírání daní.

Obdobou dnešní daně z př́ijmů právnických osob se stala na území našeho státu daň všeobecná výdělková a daň z kočovných živností. Vedle daních státních se vyskytovaly např. ještě daně zemské, do kterých se řadilo např̀. „hudebné“ $z$ pořádání tanečních zábav, daně z lístků rybářských či honebních, které se později zpravidla změnily na poplatky. ${ }^{5}$

Daňová reforma byla a je vždy zásadní, systémovou změnou celého daňového systému. Obvykle je reakcí na zásadní změnu ekonomických, sociálních či politických podmínek a má

\footnotetext{
${ }^{2}$ Ve Francii se ve 14. století začala objevovat např. daň z krbů a ohništ'. V Čechách a na Moravě se od roku 1546 vybírala daň z piva, tzv. „posudné“. Název byl odvozen od výchozí berní jednotky - prodaného či vyšenkovaného sudu piva. S výnosem z této daně mohl disponovat výlučně panovník. Později nap̌r. württemberský vévoda Karl Eugen v roce 1789 zavedl vrabčí daň. Vzhledem k přemnožení vrabců, kteří požírali osivo na polích, vévoda nařídil, aby každý obyvatel v problematických oblastech ulovil 12 vrabců. Kdo je odevzdal, dostal šest krejcarů. Kdo si svou povinnost nesplnil, musel zaplatit 12 krejcarů.

${ }^{3}$ Smith A.:Pojednání o podstatě a původu bohatství národů, SNPL Praha 1958, Díl druhý str.392 a násl.

${ }^{4}$ Déjiny Francie. Nakladatelství Svoboda, Praha 1988, s. 336 a násl.

${ }^{5}$ Vznik daně z př́ijmů je spojován s rokem 1799 a Velkou Británii. Výše daně byla $10 \%$ na všechny př́ijmy nad 200 liber - roku 1815 byla zrušena, ale r.1842 již natrvalo obnovena. Itálie zavedla daň z př́ijmů v roce 1864, Francie v roce 1914 a USA v roce 1913.
} 
za úkol těmto změněným podmínkám daňovou soustavu přizpůsobit, zabezpečit ekonomický růst a větší daňovou spravedlnost. Daňovou reformou není tedy pouhá změna sazeb, slev, nezdanitelných částek a podobně, byt' někteří mají sklon takovéto dílčí změny za reformu označovat.

V moderní historii samostatného Československa či České republiky došlo ke třem zásadním reformám (pomineme-li ovšem období okupace českých zemí nacistickým Německem).

První daňová reforma v samostatném Československu byla provedena zákonem č. 76/1927 Sbírky zákonů a nařízení, o přímých daních, ze dne 15. června 1927. Hlavními důvody pro tuto reformu byly následující potřeby státu:

- unifikace daňových předpisů v Československu, kde až doposud platily zákony z doby Rakousko-Uherska, které byly jiné v českých zemích a jiné na Slovensku a Podkarpatské Rusi;

- $\quad$ soustředění až doposud roztříštěných zákonů o přímých daních do jednoho přehledného a srozumitelného zákona;

- promítnutí důsledků dosažené stabilizace československé měny do systému přímých daní;

- přizpůsobení přímé daně zásadě daňové únosnosti;

- reakce na politické a ekonomické změny způsobené vznikem samostatného státu. ${ }^{6}$

Jak již vyplývá z názvu zákona je zřejmé, že reforma se týkala pouze přímých daní. ${ }^{7}$ Zákon o prímých daních však obsahoval i další části - jednak trestní ustanovení, která upravovala postup při zjištěném zkrácení daně a při porušení dalších povinností, a jednak tzv. společná ustanovení, která představovala ve skutečnosti procesní ustanovení (obdobu dnešního daňového řádu). Ve své době to byl velice moderní, srozumitelný a kvalitní zákon, který řada odborníků dodnes považuje za nejkvalitnější daňový zákon historie.

Po skončení druhé světové války byl na území Československa obnoven (až na výjimky) právní řád platný v roce 1938, což platilo i o daňovém systému. Ovšem velice rychle se začal daňový systém měnit s přihlédnutím k novým ekonomickým a politickým poměrům. Prvním

\footnotetext{
${ }^{6}$ Důvodová zpráva ke vládní předloze zákona o přímých daních, publikováno in. Uzel Vincenc: Zákony o berní reformě, Tiskové podniky Ústředního svazu československých průmyslníků, Praha 1927, str. 1 a násl.

${ }^{7}$ Daň z obratu a daň přepychová byly totiž nově zavedeny s účinností od roku 1920, a selektivní spotřební daně, zůstaly prakticky v podobě převzaté z Rakouska-Uherska. Zákonem o přímých daních byly upravené následující daně:

- důchodová daň, jejímž předmětem byly veškeré př́ijmy domácnosti,

- všeobecná daň výdělková, jíž podléhaly osoby nebo sdružení osob provozující svým jménem výdělečný podnik,

- zvláštní dan̆ výdělková, jíž podléhaly právnické osoby,

- pozemková dan̆,

- domovní dan̆,

- rentová daň, jíž podléhaly požitky z majetkových předmětů a práv (napřr. úroky, pachtovné atd.),

- daň z tantiém,

- daň z vyššího služného, jíž podléhaly služební požitky přesahující stanovenou částku.
} 
příznakem změny v pojetí daní byla daň ze mzdy, schválená již v roce 1947 . V roce 1948 byly zavedeny tř̀i nové daně - živnostenská, zemědělská a daň z úroků z úsporných vkladů, v roce 1950 daň z prŕijmů z literární a umělecké činnosti a daň ze samostatné činnosti. ${ }^{8}$ Tato permanentní reforma byla završena radikální jednorázovou tzv. Kabešovou daňovou reformou ${ }^{9}$, kdy dne 11. prosince 1952 Národní shromáždění během několika desítek minut jednomyslně schválilo deset zcela nových daňových zákonů, účinných od 1. ledna $1953 .{ }^{10}$ Současně byly schváleny zákony o místních rozpočtech, o organizaci peněžnictví, o pojištovnictví a zákon o kontrolní a revizní správě ministerstva financí. Cíle daňové reformy z roku 1953 spočívaly zejména $\mathrm{v}$ tom, že bylo třeba daňovou soustavu přizpůsobit plánovanému socialistickému hospodářství, kde existovaly dva cenové okruhy (maloobchodní a velkoobchodní ceny pevně stanovené státem) a monopol jak vnitřního tak i zahraničního obchodu. Cílem bylo i využít reformu jako nástroj proti zbytkům soukromých podnikatelů (jejich zdanění dosahovalo až $90 \%$, a též jako pobídku pro získání zemědělců ke členství v jednotných zemědělských družstvech. Do daňového systému se promítly ideologické prvky, zejména pokud se týká zdanění osobních př́ijmů. Daňová soustava tak byla velice ,pružná“ a to, co v civilizované zemi vyžaduje změnu zákona, bylo zde možné pouhým výnosem ministerstva financí, vyhláškou či vládním nařízením. ${ }^{11}$

Po listopadu 1989 bylo naprosto zřejmé, že daňový systém musí projít zásadní reformou a proto již v květnu 1990 zpracovalo tehdejší Federální ministerstvo financí Návrh koncepce daňové soustavy, který byl výchozím materiálem pro další práce, které vyvrcholily radikální daňovou reformou provedenou k 1. lednu 1993. Za hlavní cíle byly označeny rozpočtově politické cíle, tzn. že daňová soustava bude konstruována tak, aby zajistila elasticitu státních př́ijmů na vývoji hrubého domácího produktu, spravedlivé rozdělování prvotních důchodů, podnikově hospodářské cíle, které se projeví ve vytváření rovných konkurenčních podmínek, otevírání domácí ekonomiky, pružnost a účinnost vybírání daní, ale i finančně psychologické cíle, zaměřené na to, že daňová soustava musí odpovídat konstrukcí mentalitě našich národů a jejich právnímu povědomí. ${ }^{12}$ Př́íprava zákonů narážela $v$ té době na problémy s kompetencemi jednotlivých republik, tzn. České a Slovenské. Zákony o daních z př́ijmů a zákony o dani z přidané hodnoty a spotřebních daních patřily do kompetence federace, ostatní zákony včetně procesní úpravy do kompetence republik. V souladu s harmonogramem tak Federální shromáždění v dubnu 1992 schválilo zákony o dani z přidané hodnoty, o spotřebních daních a o daních z př́ijmů, a také zákon č. 212/1992 Sb., o soustavě daní, který měl zabezpečit, aby i

\footnotetext{
${ }^{8} \mathrm{~V}$ roce 1948 byla namísto daně z obratu zavedena tzv. všeobecná daň po vzoru prvních sovětských pětiletek. Lze tedy ř́íci, že od roku 1947 byl daňový systém v neustálém pohybu.

${ }^{9}$ Jaroslav Kabeš byl $\mathrm{v}$ té době ministrem financí

${ }^{10}$ Byly zavedeny daň z obratu (ovšem daň z obratu zcela odlišná od tehdy používaných daňových systémů, vycházející ze státního dirigismu cen a z monopolu zahraničního i vnitřního obchodu), daň z výkonů, důchodová daň, jejímiž poplatníky byla zejména družstva (kromě zemědělských), daň ze mzdy, zemědělská daň, daň z př́ijmů obyvatelstva, živnostenská daň, domovní daň, daň z představení, místní poplatky.

${ }^{11}$ Ostatně se úsměvně ř́kalo, že zákon o dani z obratu zní takto: „Zavádí se daň z obratu. Ostatní stanoví ministr financí." Nahlédnutím do zákona č. 73/1952 Sb., o dani z obratu (platil až do konce roku 1992, tedy 40 let!), zjistíme, že to je téměř pravda - vše potřebné pro jeho aplikaci, a to včetně sazeb, mělo podobu výnosů ministerstva financí nebo později alespoň zčásti vyhlášek.

${ }^{12}$ podrobněji viz Boněk V.: K historii daňových reforem v českých zemích, Daně a finance č. 11/2007 s. 3 a násl.
} 
daně, které byly v kompetenci republik, se alespoň co do předmětu daně nelišily. Dnem 1. ledna 1993 vznikla samostatná Česká republika a samostatná Slovenská republika a stejným dnem v obou státech nabyly účinnosti zcela nové daňové zákony. V roce 1993 tak začaly být účinné zákony zcela nové, zavedené nejradikálnější daňovou reformou naší historie, které jsou postupně měněny a je tak otázkou, zde má dojít $\mathrm{k}$ další daňové reformě či nikoliv a v jakém smyslu.

\section{MOŽNOSTI ŘEŠENÍ ROZPOČTOVÝCH PŘÍJMŮ A VÝDAJŮ STÁTU PO PANDEMII}

Současná pandemie vytvořila tlak na stát, aby ze svých zdrojů poskytl pomoc podnikatelům, zachoval nejen zaměstnanost, ale pomohl i samotným podnikatelským subjektům. Př́ijmy státu v podobě daní byly $\mathrm{v}$ důsledku nastalé situace omezené. $\mathrm{V}$ př́ípadě státního rozpočtu se v roce 2020 meziročně snížily o 3,1\%, což se nejzřetelněji projevilo u daňových př́ijmů bez pojistného o $6,1 \%$ (-46,5 mld. Kč). Inkaso vylepšovaly př́ijmy z Evropské unie a finančních mechanismů s nárůstem o $8,3 \%$ (+10,4 mld. Kč $).{ }^{13}$ Dopad ekonomického vývoje na inkaso daní se plně promítne ve zúčtování daňových povinností v roce 2021, protože řada subjektů neměla povinnost platit zálohy na daně.

Podpora vyplácená formou kompenzačních bonusů v celkové výši 24,4 mld. Kč a pokles objemu mezd a platů dopadly na inkaso daně z př́ijmů fyzických osob placené plátci. Na inkasu daně $\mathrm{z}$ přidané hodnoty se zase negativně podepsal pokles maloobchodních tržeb v důsledku uzavření obchodu a služeb (což bude pokračovat i v roce 2021). Inkaso spotřebních daní bylo rovněž negativně ovlivněno dopady opatření zaváděných k zastavení šíření nákazy nemoci COVID-19. Významné dopady byly zaznamenány u spotřební daně z minerálních olejů, což bylo spojeno $\mathrm{s}$ výrazným úbytkem přepravních výkonů. $\mathrm{Z}$ důvodu uzavření restauračních zařízení a omezeného turistického ruchu nastal propad i v prŕípadě inkasa spotřební daně z lihu. Pouze inkaso spotřební daně z tabákových výrobků - díky navýšení sazeb spotřební daně meziročně vzrostlo v roce 2020 o 6,4 \%. ${ }^{14}$ Je tedy zřejmé, že stát sahá při řešení rozpočtových př́ijmů k ekonomickým nástrojům, které má k dispozici - zajištění vyššího výběru daní event. nutnosti připustit určitý růst zadlužení.

Zatím v našem daňovém systému nenajdeme vyloženě bizardní daně, ale není vyloučeno, že se můžeme i v České republice dočkat některých daní, které již jsou zavedeny v některých evropských státech. V záměru bojovat za zdravější populaci se v řadě států už zavedla daň na určité "nezdravé " potraviny. Zdanění spočívá v tom, že nápoje a pokrmy s vyšším než stanoveným obsahem tuku či cukru jsou zdaněny dodatečnou sazbou daně. Vzhledem k tomu, že to byl už v roce 2012 i nápad Národní ekonomické rady vlády (NERV) v České republice, je možné že v současné ekonomické situaci se v nějaké podobě tento návrh vrátí.

Majetkové daně byly v minulosti oblíbenou formou zdanění a není vyloučeno, že se v nějaké formě návrhy na změnu daně z nemovitých věcí objeví i jako návrh nové vlády.

\footnotetext{
${ }^{13}$ COVID-19 a jeho vliv na hospodaření státního rozpočtu v roce 2020 - př́ijmy, Obec a finance č.1/2021 s. 6-9.

${ }^{14}$ tamtéž
} 
Odůvodněním může být i to, že české daně dopadající na majetek jsou ve srovnání se světem nízké a byla by to cesta $\mathrm{k}$ získání dalších finančních zdrojů do rozpočtu. Podoba daně z nemovitých věcí by se však musela změnit nejen co do podstaty daně, ale i jejího výběru. Přejít na zdanění majetku např. podle jeho hodnoty by bylo řešením, ale zatím není nabízen ani postup takového řešení (je otázkou např. to, jak by se do daně promítalo zhodnocení či znehodnocení majetku, kdo by to posuzoval apod.) Nejde jen o možnost zvýšit sazbu daně bez dalšího, ale řešit i otázky správy daně či rozpočtového určení nejen této daně.

Další možností, o které se již řadu let hovoří, je zavedení tzv. sektorových daní. Zde by však byla nutná koordinace v rámci EU. Jako o sektorové dani se mluví v př́́padě zdanění konkrétních sektorů ekonomiky daní v jiné výši než je zdanění ostatních právnických osob. Jedná se tedy primárně o speciální daň uvalenou na právnické osoby podnikající ve vybraném sektoru. Společnou vlastností takových plateb je, že uvalují na podnikající ekonomický subjekt platební povinnost, která pro něj představuje ekonomický náklad. Sektorová daň se může objevit jako speciální sazba daně z př́ijmů právnických osob či v podobě určité přirážky $\mathrm{k}$ této dani. V české právní úpravě povinných plateb však již existují různé druhy poplatků, dávek, odvodů, př́spěvků, úhrad, které dopadají na některé oblasti podnikání a představují tak $\mathrm{k}$ dani z př́ijmů další náklad pro tato odvětví ekonomické činnosti, aniž by se označovaly jako sektorové daně. Pojem daň v širokém slova smyslu však takové platby zahrnuje. ${ }^{15}$ Konkrétní podoba sektorové daně by měla zohlednit specifičnost jednotlivých odvětví. V úvahu pro řešení rozpočtových příjmů tak přichází různé sazby daně z př́ijmů právnických osob na úrovni daných odvětví s ohledem na velikost subjektů na trhu. Jednalo by se o zavedení progresivity zdanění právnických osob (pravděpodobně ve formě pásmového progresivního zdanění). Mezi technické způsoby, které prrichází obecně do úvahy k aplikaci zvýšené sazby daně, jako sektorové daně patří:

- druhá sazba daně z př́ijmů právnických osob pro vymezené sektory

- přirážka $\mathrm{k}$ dani $\mathrm{z}$ prŕíjmů právnických osob pro vymezené sektory ${ }^{16}$

- jako nepřímá daň sazba daně z přidané hodnoty pro vymezené zboží a služby spojené s danými sektory.

V souvislosti se sektorovou daní hovoří zejména o sektoru finančnictví, který zahrnuje bankovnictví a pojišt'ovnictví a dále o odvětví telekomunikací a energetiky. ${ }^{17}$

Jako reálná se jeví také úprava DPH vzhledem k tomu, že nedostatek př́immů budou řešit i ostatní státu EU.

\footnotetext{
15 podrobněji např. Karfíkova M. a kol. Teorie finančního práva a finanční vědy. Praha: Wolters Kluwer ČR, 2018 s. 147 a násl.

${ }^{16}$ Přirážky k daním znala česká právní úprava již v období 1.republiky, ale v té době to byl nástroj řešení prř́jmů obcí.

$17 \mathrm{~V}$ českém právní řádu v současné době můžeme označit jako určitou formu sektorového zdanění zdanění hazardu. $\mathrm{V}$ tomto případě se nejedná pouze o ekonomické důvody pro zvláštní zdanění ve smyslu dosahování nadstandardního zisku tohoto odvětví, ale také o sociální dopad hazardu.
} 


\section{DOPADY ROZPOČTOVÝCH ZMĚN NA MÍSTNÍ SAMOSPRÁVU}

$\mathrm{V}$ Evropě se již před řadou let projevila potřeba stanovení určitých principů pro sjednocování místní samosprávy a jejich hospodaření - včetně otázek rozpočtových, která vedla k prrijetí Evropské charty místní samosprávy (dále jen Charta) ${ }^{18}$.

Finanční zdroje místních společenství jsou považovány za jednu ze základních ústavních záruk plnění úkolů místních samospráv a Charta rozebírá tuto problematiku ve svém článku 9. Tento článek říká, že alespoň část finančních zdrojů místních společenství pochází z místních daní a poplatků, jejichž sazbu mohou místní společenství v mezích zákona stanovit. Jde o princip určité dílčí daňové autonomie, která se však u nás realizuje jen v určité omezené mîře a navíc se Česká republika necítí být oficiálně vázána touto zásadou Charty. ${ }^{19}$

O finanční autonomii se dá hovořit tehdy, kdy jsou vlastní př́íjmy rozpočtů územních celků zajištěny př́ślušným zákonem, výkon samosprávy není omezován státním dozorem nad jejich hospodařením s veřejnými prostředky, ale státní dozor funguje na přijímání dluhových prostředků. Porovnáme-li jednotlivé znaky finanční autonomie se skutečností u nás, můžeme říci, že existují př́slušné zákony, které zajišt'ují územním celkům vlastní finanční zdroje, i když tyto vlastní zdroje zpravidla nestačí na pokrytí všech potřeb územních celků a musí být doplněny z centrálních zdrojů.

Princip zdaňovací pravomoci může být teoreticky realizován např. i přirážkami $\mathrm{k}$ centrálně stanoveným daním nebo možností stanovit vlastní daně. Přirážky ke státním daním byly u nás realizovány v období první republiky, v současné době možnost toho druhu př́imu obcím ani krajům dána není. Vlastní místní daně (pokud za ně nebudeme považovat místní poplatky) si místní společenství také dosud nemohou zavádět ${ }^{20}$.

Druhý požadavek Charty- neomezovat výkon samosprávy při hospodaření s veřejnými prostředky - je sice realizován, ale s určitými specifiky. V české právní úpravě najdeme ustanovení týkající se kontroly hospodaření za uplynulý rok, jsou stanovena pravidla nakládání $\mathrm{s}$ rozpočtovými prostředky získanými ze státního rozpočtu či rozpočtové odpovědnosti apod. Dozor nad dluhovou oblastí je tak sice zajištován státem, ale dá se konstatovat, že je to

\footnotetext{
${ }^{18}$ Jedná se o rámcovou mezinárodní smlouvu s možností př́istupu dalších států. Charta vstoupila v platnost již v roce 1988, ale česká vláda až unesením č. 331/1998 připojila svi̊j podpis $\mathrm{k}$ této Chartě a dnem 1.9.1999 vstoupila tato Charta v platnost pro naši republiku sdělení ministra zahraničních věcí publikované pod č.181/1999 Sb. Textem pěti z nich je Česká republika vázána, třemi odstavci vázána není - uplatnila výhradu.

19 Marková H. Fiscal Decision-making of Self-governing Regional Authorities. In: Public Finances administratives autonomies. Györ, 2012. ISBN 978-963-9.

${ }^{20}$ Pro srovnání je možné uvést rok 1927. V tomto roce došlo na našem územní $\mathrm{k}$ významné reformě veřejné správy, byla provedena reforma př́mých daní a hospodaření jednotlivých stupňủ územní samosprávy, i úprava sociálního pojištění. Hlavním rysem všech těchto změn bylo uplatnění principu solidarity mezi svazky územní samosprávy. Tehdy byla právní úprava postavena na třech hlavních institutech, a sice přirážkovém limitu, tzv. vyrovnávacích fondech a úpravě rozpočtu. Byly zrrízeny tzv. zemské vyrovnávací fondy na pomoc oddlužení obcí a okresů, které byly finančně zajištěny $z$ veřejnoprávních výnosů, a to domovní daně (na níž neměly nárok obce), části pozemkové daně a části daně přepychové. Země mohly z tohoto fondu poskytovat finančně slabým okresům a obcím podpory na úhradu schodku jejich hospodaření, dotace na krytí rozpočtových potřeb apod., aby se již dále tyto celky nemusely zadlužovat a měly pokryty rozpočtové potřeby. Avšak teprve když obce ani všemi nástroji, které jim zákon umožňoval, nedosáhly na vyrovnanost rozpočtu, dostávaly podporu ze zemského vyrovnávacího fondu. Zesílil v té době také dozor vy̌šśích orgánů nad sestavováním a plněním rozpočtů nižších stupňủ samosprávy.
} 
v rozsahu, který neomezuje výkon samosprávných funkcí územních celků. Možnosti územních rozpočtů jsou tak v současné době do značné míry omezeny při získávání dalších příjmů a jsou závislé na státním rozpočtu, který do těchto rozpočtů přesunuje část vybraných daní cestou rozpočtového určení daní či v podobě dotací.

\section{NÁRODNÍ ROZPOČTOVÁ RADA A JEJí POSTOJ K ŘEŠENÍ ROZPOČTOVÝCH PROBLÉMŮ}

Národní rozpočtová rada je nezávislý odborný orgán, jehož hlavním posláním je vyhodnocovat, zda stát a další veřejné instituce dodržují pravidla rozpočtové odpovědnosti ${ }^{21}$ daná zákonem. Činnost Národní rozpočtové rady má přispívat k udržitelnosti veřejných financí České republiky a snižování rizika nadměrného zadlužování státu. Stanoviska a zprávy vydávané Národní rozpočtovou radou slouží jako podklady pro vládu České repbuliky, Poslaneckou sněmovnu a územní samosprávy tak, aby mohly co nejpřesněji a nejodpovědněji plánovat a provádět fiskální a rozpočtovou politiku.

Národní rozpočtová rada ${ }^{22}$ se ve svém stanovisku k vývoji hospodaření z 3.června 2021 zabývala otázkou revize výdajů a upozornila, že důsledkem omezování těchto výdajů nemůže být nic jiného než zvyšování daňové zátěže. Redukce různých osvobození od daně, odpočtů od základu daně, slev a dalších konstrukčních prvků ve svém důsledku zvyšuje průměrnou daňovou sazbu, a to bud' všeobecně nebo pro specifické skupiny poplatníků. Rozsah výdajů ve veřejných rozpočtech je sice na první pohled značný, ale vesměs se jedná o prvky plnící důležité sociální a stimulační funkce. Např. Ministerstvo financí odhaduje, že již v roce 2018 dosáhla hodnota daňových výdajů u tř́i nejvýznamnějších daní (obě daně z př́jimů a daň z přidané hodnoty) částky 520 mld. Kč a $z$ toho připadalo téměř 300 mld. Kč na osvobození zdaňování důchodů a sociální slevy (na poplatníka, na děti atd.) u daně z př́ijmů fyzických osob, 134 mld. Kč na osvobození vybraných plnění u DPH (napřs. nájmy nemovitých věcí) a dále 57 mld. Kč na existenci snížených sazeb DPH. Je tedy zřejmé, že prostor pro omezování těchto výdajů, který by neměl dopady na většinu populace (at' již v podobě snížení disponibilního důchodu nebo zvýšení cen) je omezený a rozhodně nemůže zajistit splnění celkové konsolidační potřeby, kterou by veřejné rozpočty potřebovaly. ${ }^{23}$

Národní rozpočtová rada konstatovala, že musí být zpracována důvěryhodná konsolidační strategie zajišt'ující zabránění kolizi s dluhovou brzdou a že konsolidační úsilí musí být v letech 2022 a 2023 vyšší než avizovaných $0,5 \%$ HDP. ${ }^{24}$

\footnotetext{
${ }^{21}$ podle zákona č. 23/2017 Sb., o rozpočtové odpovědnosti, ve znění pozdějších předpisů.

22 https://unrr.cz/nrr-vydala-pravidelne-ctvrtletni-stanovisko-k-vyvoji-hospodareni-sektoru-verejnych-instituciupozornuje-v-nem-na-nedostatecne-ambiciozni-plan-konsolidace/.

${ }_{23}$ https://unrr.cz/nrr-vydala-pravidelne-ctvrtletni-stanovisko-k-vyvoji-hospodareni-sektoru-verejnych-instituciupozornuje-v-nem-na-nedostatecne-ambiciozni-plan-konsolidace/

${ }^{24}$ NRR se domnívá, že konsolidační úsilí musí být v letech 2022 a 2023 vyšší než avizovaných $0,5 \%$ HDP. Celková konsolidace, kterou bude nutné realizovat pro návrat na úroveň $1 \%$ strukturálního deficitu, činí v současné době 5,5 \% HDP a je zřejmé, že konsolidaci v takovém rozsahu nebude možné realizovat pouze přes omezování veřejných výdajů a bude nutné přistoupit i k ne nevýznamnému zvýšení daňové zátěže, a to at' už v podobě zvyšování daňových sazeb, nebo úpravou jiných konstrukčních prvků daně.
} 
Úřad Národní rozpočtové rady uvedl ve své studii, ${ }^{25}$ že vedle propadu př́ijmů veřejných rozpočtů a $\mathrm{k}$ nárůstu deficitů veřejných rozpočtů budou přispívat i opatření vlády na prŕíjmové i výdajové straně, která mají podpořit domácí ekonomiku a zamezit hromadným bankrotům. Ve zmíněné studii jsou uváděny dopady do rozpočtu pro rok 2020, ale nejsou vyčíslena opatření, která mají výrazný dopad na ekonomiku i když nemají prŕímý dopad na veřejné rozpočty. Jsou to opatření, která se rozpočtově projeví jak roce 2021, ale zejména později (prríkladem nezahrnutých opatření jsou např. regulace vztahů mezi nájemci a nájemníky, umožnění odkladů splátek bankovních i nebankovních úvěrů apod.) V těchto př́padech vláda de facto přesunuje náklady spojené s neschopností splácet ze strany osob zasažených epidemií a regulacemi, na jiné subjekty. Nejsou zohledněny ani eventuální náklady vlády spojené s př́ípadnými soudními spory, stejně jako náklady na kompenzace postiženým subjektům nad rámec oficiálních programů, které by mohly vyplynout ze soudních sporů o náhradu škody, náklady spojené s nejrůznějšími zárukami za úvěry, poskytnutím bezúročných úvěrů či odkladem plateb daní. ${ }^{26}$ Jako př́klad výdajových opatření, která mají dopad do rozpočtu, jsou uvedeny programy na podporu zaměstnanosti a přímé kompenzační bonusy směřované převážně na osoby samostatně výdělečně činné. Celkové náklady na tato opatření odhadl Úřad národní rozpočtové rady na 76 mld. Kč. Je nutné dodat, že kromě uvedených výdajů nebyla řada věcí do studie zahrnuta - např̀ dopady opatření typu odpuštění nájemného za komerční prostory, které mohou mít nezanedbatelné dopady především u municipalit.

Rovněž se nepočítalo s výpadkem příjmů státního rozpočtu, které mohou ovlivnit státní rozpočet napřr. nezavedení digitální daně (vliv cca $2 \mathrm{mld}$. Kč) či nižší nárůst resp. pokles př́ijmů z mýtných systémů. Podobným způsobem může působit i pokles nedaňových př́ijmů státu např př́ijmy z dividend státem kontrolovaných podniků (Lesy ČR, Letiště Praha).

Podobně se mohou propadnout př́jmy obcí z poplatků spojených s turistickým ruchem či poplatků v parkovacích zónách.

\section{ZÁVĚR}

V důsledku vyšších výdajů státního rozpočtu bude muset být rozdíl mezi př́ijmy a výdaji veřejných rozpočtů nějakým zpo̊sobem kompenzován. Je otázkou, zda to má být novými daněmi a koho by měly tyto daně zatížit či má dojít u daně z příjmů k zavedení větší progrese nebo se má řešit rozpočtový problém vyšším zadlužením státu. Přerozdělování finančních

\footnotetext{
${ }^{25}$ https://unrr.cz/wp-content/uploads/2020/04/Informační-studie-Fiskální-náklady-pandemie-Covid-19-v-Českérepublice.pdf.

${ }^{26}$ Například programy COVID I a II, nebo zvýšení pojistné kapacity Exportní garanční a pojištovací společnosti, a.s. U těchto typů opatření jsou jejich náklady obvykle rozloženy do celé doby existence úvěru či záruky, přičemž dopad v roce 2020 bude zřejmě relativně omezený. Náklady zde souvisejí jednak s náklady financování ze strany státu, které je možné odhadnout výno sem státních dluhopisů. Druhým typem nákladů jsou ztráty související s nesplácením těchto úvěrů,resp. realizace záruk. Tyto náklady by bylo možné aproximovat podílem nesplácených úvěrů zlet, kdy vrcholily dopady předchozí finanční a dluhové krize. Celkové dopady všech těchto opatření by v roce 2020 mohly činit cca 2 mld. Kč - podrobněji viz https://unrr.cz.
} 
zdrojů ze státu na další veřejné rozpočty či jiné subjekty např. cestou dotací, přináší další problémy, které se v situaci, jakou je pandemie, ukazují jako obtíženě řešitelné.

Volbu nástrojů na posílení př́ijmů státu a zároveň i obcí a krajů, které jsou na daňových př́ijmech státu také závislé, bude tř̌eba řešit v krátké době a bude to náročný úkol. Vzhledem $\mathrm{k}$ tomu, že pandemie postihla celý svět, bude řešení problémem celé EU. Dá se očekávat, že oblast nepřímých daní bude tou první, které se změny dotknout. To však neznamená, že přímé daně se nezmění, ale to už bude záležitost jednotlivých států a jejich preferencí.

Jak bylo výše uvedeno, řešení př́ijmů státu v návaznosti na rostoucí požadavky výdajové stránky rozpočtu bude znamenat výrazné zásahy nejen do daňové soustavy, ale bude třeba řešit i dopad do struktury výdajů státu, bude znamenat i nutnost rozhodnout o stupni přerozdělování vybraných př́ijmů $\mathrm{v}$ návaznosti na oblasti které má zajistit stát a ty, které jsou ve sfére rozhodování obcí a krajů. V tomto směru má ČR velký problém ve značném počtu obcí - přes 6000 - s rozdílnou velikosti, i s rozčleněním na kraje, také s různým počtem obyvatel. Nároky na spravedlivé přerozdělení prostředků získaných z daní pro obecní a krajské rozpočty tak jsou a budou komplikované. Možná se oživí diskuse o možnosti zavádění místních daní, které předpokládá Charta místní samosprávy a o kterých se vedla diskuse i v ČR v roce 2001. Návrh zákona o obecních daních, který měl tuto změnu přinést, byl předložen vládou v roce 2001, ale nebyl schválen Poslaneckou sněmovnou ${ }^{27}$. Do přerozdělovacích procesů vstupují v ČR ještě platby na zdravotní pojištění, které mají jiný mechanismus výběru a užití získaných zdrojů než daně. Dalším problémem je důchodový účet v rámci státního rozpočtu a řešení otázky důchodů.

Celý systém zajištění rozpočtových zdrojů tak, aby dostatečně pokryly rostoucí potřeby státu a jeho článků (krajů a obcí) je náročný na správu což odčerpává také značnou část zejména daňových př́ijmů.

Historie zná různé daňové povinnosti, které byly zaváděny při nedostatku př́ijmů, které stát potřeboval a kterými reagoval na možnosti, které v dané době byly k dispozici.

Nabízí se otázka, jak postupovat v současnosti, zda je možné ještě něco zdanit či volit jinou cestu. Potřeba úhrady výdajů jen na ty nejnutnější potřeby, povede $\mathrm{k}$ tomu, že se další oblasti potřeb společnosti dostanou do pozadí. Na rozdíl od původního závazku státu v souvislosti s řešením problému pandemie COVIDU 19, a to pouze dočasném snížení daně z prŕijmů fyzických osob, se nyní uvažuje o dalších cestách získání rozpočtových prříjmů, jako je zvyšování daní ze spotřeby, zdaňování globálních společností a také cesta revize rozpočtových výdajů. ${ }^{28}$ Je však zřejmé, že prostor pro omezování výdajů, který by neměl dopady na většinu populace (at' již v podobě snížení disponibilního důchodu nebo zvýšení cen) je omezený a rozhodně nemůže zajistit splnění celkové konsolidační potřeby. Řešením tak asi bude čtvrtá daňová reforma v ČR.

\footnotetext{
${ }^{27}$ podrobněji viz Marková H. Vlastni nebo sdílené daně obcím? MU Brno 2007, s. 203-2012.

${ }^{28}$ https://unrr.cz.
} 


\section{POUŽITÁ LITERATURA}

1. Boněk V. K historii daňových reforem v českých zemích. In Daně a finance č. 11/2007. s. 3 a násl. ISSN 1801-6006.

2. Karfíkova M. a kol. Teorie finančního práva a finanční vědy. Praha Wolters Kluwer ČR, 2018 s.147 a násl. ISBN 978-80-7552-935.

3. Marková H. Vlastní nebo sdílené daně obcím? MU Brno 2007, s .203-2012. ISBN 978-80-210-4430.

4. Marková H. Fiscal Decision-making of Self-governing Regional Authorities. In Public Finances - administratives autonomies. Györ, 2012. 817 S. ISBN 978-963-9819-870 .

5. Smith A. Pojednání o podstatě a původu bohatství národi̊. SNPL Praha 1958, Díl druhý str. 392 a násl.

6. Dějiny Francie. Nakladatelství Svoboda, Praha 1988, s. 336 a nás1.

7. COVID-19 a jeho vliv na hospodaření státního rozpočtu v roce 2020 - př́ijmy. In Obec a finance č. 1/2021, s.6-9, ISSN 1211-4189.

\section{KONTAKT NA AUTORA}

prof. JUDr. Hana Marková, CSc.

markova@prf.cuni.cz

Univerzita Karlova, Právnická fakulta

nám. Curieových 7

11640 Praha 1

Česká republika 